\title{
Comparison of cardiotoxicity of levobupivacaine and bupivacaine with the brain natriuretic peptide
}

\section{Levobupivakain ve bupivakainin kardiyotoksisite-sinin B-type natriüretik peptid ile karşılaştırılması}

\author{
Korgüin Ökmen M.D. a, Nermin Gööğüiș M.D. ${ }^{b}$
}

University of Health Sciences, Bursa Yuksek Ihtisas Training and Research Hospital, Department of Anesthesiology and Reanimation, Bursa/TURKEY

b. University of Health Sciences, Ankara Numune Training and Research Hospital, Department of Anesthesiology and Reanimation, Ankara/TURKEY Corresponding author: Korgün Ökmen (M.D.),University of Health Sciences, Bursa Yuksek Thtisas Training and Research Hospital, Department of Anesthesiology and Reanimation, Mimar Sinan Quarter. Emniyet Street. 16130 Bursa/TURKEY.

E-mail: korgunokmen@gmail.com

Received/Accepted: January 22, 2018 / June 21, 2018

Conflict of interest: There is not a conflict of interest.

\section{SUMMARY}

Objective: Local anesthetics are also considered to be potentially toxic to the cardiovascular system since they act on ion channels in nerve cell membranes as well as in other tissues that can be stimulated.In this study we aimed to compare cardiotoxicity levels of both drugs with brain natriuretic peptide (BNP) protein level in patients undergoing combined spinal epidural anesthesia and postoperative analgesia when given bupivacaine and levobupivacaine at equipotent doses. Method: In this prospective, randomized, double-blind study a total of 30 patients, aged 25-70 years, who were included in the American Society of Anesthesiologists (ASA) I-III risk class and underwent total knee arthroplasty surgery, were included in the study. Patients were randomized as Group I $(n=15)$ Levobupivacaine and Group II $(n=15)$ bupivacaine and combined spinal-epidural anesthesia was administered. The operation follow-up of patients were evaluated with the systolic arterial pressure (SAB), the diastolic arterial pressure (DAB), the mean arterial pressure (MAP) and the heart rate (HR), and postoperative follow-up with $\mathrm{SAB}, \mathrm{DAB}, \mathrm{KH}$, visual analogue scale (VAS) values were monitored at zero minute, 1st, 6th, 12th and 24th hour. BNP levels were measured at 5th minute after spinal anesthesia, sensory block at thoracal level 10 and post-operative 24th hour.

Results: A statistically significant difference was found in the VAS values measured at postoperative 12th hour and 24th hour in favor of levobupivacaine group $(\mathrm{p}<0.05)$. In the comparison of BNP levels between the groups, there was no statistically significant difference between the two groups at all measurement times ( $\mathrm{p}>0.05)$.

Conclusions: Similar results were obtained in intraoperative and postoperative BNP levels when using levobupivacaine and bupivacaine in equal doses for both spinal anesthesia and epidural analgesia.

Keywords: Bupivacaine, Levobupivacaine, Brain Natriuretic peptide, Cardiotoxicity

\section{ÖZET}

Amaç: Lokal anestezikler, sinir hücre membranlarındaki iyon kanalları üzerinden oluşturdukları etkileri, uyarılabilir diğer dokularda da oluşturduklarından kardiyovasküler sistem için de potansiyel toksik olarak kabul edilmektedirler.Bu çalışmada, levobupivakain ve bupivakainin kombine spinal-epidural anestezi ve analjezideki kardiyotoksisite etkilerini B-type natriüretik peptid (BNP) protein düzeyiyle saptamayı amaçladık

Yöntem: Bu prospektif, randomize, çift kör çalışmada 25-70 yaşları arasında American Society of Anesthesiologists (ASA) I-III sinıfinda olan ve total diz artroplastisi cerrahisi uygulanan toplam 30 hasta dahil edildi. Hastalar Grup I ( $\mathrm{n}=$ 15) Levobupivakain and in Grup II $(n=15)$ Bupivakain olacak şekilde randomize edildi ve kombine spinal-epidural anestezi uygulandı. Hastaların ameliyat sırasındaki takipleri sistolik arteriyal basınç (SAB), diastolik arteriyal basınç (DAB), ortalama arteriyal basınç (OAB)] ve kalp atım hızı (KAH) ve ameliyat sonrası takipleri ise 0. dakika ve 1., 6., 
12., 24. saatlerde $\mathrm{SAB}, \mathrm{DAB}, \mathrm{KH}$, vizüel analog skala (VAS) değerleri izlenerek yapıldı. Spinal anestezi sonras1 5. dakika, Duyusal blok Torakal 10 düzeyinde ve ameliyat sonrası 24. saat BNP düzeyleri ölçüldü.

Bulgular: Postoperatif 12. ve 24. saatteki VAS değerlerinde levobupivakain grubu lehine istatistiksel olarak anlamlı fark bulundu $(\mathrm{p}<0.05)$. Gruplar arası BNP düzeylerindeki karşılaştırmada tüm ölçüm zamanlarında her iki grup arasında istatistiksel olarak anlamlı bir fark saptanmadı $(\mathrm{p}>0.05)$.

Sonuç: Levobupivakain ve bupivakainin hem spinal anestezi hem de epidural analjezi için eşit dozlarda kullanımında intraoperatif ve postoperatif BNP düzeylerinde benzer sonuçlara ulaşı1 1 ıştır.

Anahtar sözcükler: Bupivakain, Levobupivakain, Brain Natriuretic peptid, Kardiyotoksisite

\section{INTRODUCTION}

Regional anesthesia methods are currently being used for postoperative pain palliation as well as for surgical applications ${ }^{1}$. Neuroaxial blocks such as spinal and epidural can be used individually or in combination 1. Combined spinal epidural anesthesia (CSEA) in which spinal and epidural anesthesia are applied together with a special set because they have different disadvantages when applied individually, are provided with a rapid start by spinal application and the duration of operation can be prolonged via epidural catheter and analgesia can be achieved in postoperative period ${ }^{2}$. For this purpose, local anesthetic (LA) and local anesthetic + opioid combinations can be used individually. Although there are positive aspects compared to general anesthesia, direct cardiac side effects and indirect cardiac side effects due to sympathetic denervation can be seen in relation to the chemical structure and block level of LA used 3 .

Local anesthetics are also considered to be potentially toxic to the cardiovascular system since they act on ion channels in nerve cell membranes as well as in other tissues that can be stimulated ${ }^{4,5}$. One of the most commonly used local anesthetics called Bupivacaine is the most prominent cardiac depressant ${ }^{6,7}$. Levobupivacaine, another local anesthetic used for epidural and spinal anesthesia, is a newer drug. Bupivacaine's s (-) enantiomer, Levobupivacaine, has similar pharmacokinetic properties to racemic bupivacaine. Although studies have shown that levobupivacaine has less cardiovascular side effects than bupivacaine, and that anesthetic, analgesic and hemodynamic effects after intrathecal administration are similar to bupivacaine, there are also studies that report different opinions ${ }^{6,7}$.

Natriuretic peptides are produced by the heart and are released by the ventricular myocardium in response to increased left ventricular wall tension and volume ${ }^{8}$. A number of studies on non-surgical patients with or without symptomatic heart disease have shown that brain natriuretic peptide (BNP) has a diagnostic and prognostic value in possible myocardial injury ${ }^{8}$.We hypothesize that levobupivacaine is less cardiotoxic than bupivacaine.

In our study we aimed to compare cardiotoxicity levels of both drugs with BNP protein level, a cardiac burden indicator, in patients undergoing combined spinal epidural anesthesia and postoperative analgesia when given bupivacaine and levobupivacaine at equipotent doses.

\section{MATERIAL AND METHODS}

For this prospective, randomized, double-blind study, 40 patients admitted to total knee replacement (TDP) surgery with combined spinal epidural anesthesia were evaluated for compliance after local ethics committee's approval was obtained.(Ankara Numune Education and Research Hospital Ethics Committee. Ethical number: 2008/4)

\section{Patients:}

The inclusion criterias were: 1) between the ages of $20-70,2)$ those who agreed to participate in the study, 3) patients included in the ASA I-III risk class

Exclusion criterias were: 1) presence of a cardiac disease, 2) use of known cardiotoxic drug, 3) use of alcohol, 4) smoking, 5) systemic disease such as diabetes mellitus (DM), hypertension (HT), 6) infection in the lumbar region, 7) those with anomalous deformities in the lumbar region, 8) those with hypersensitivity to the agents to be used in the study, 9) patients with neuromuscular disease, 10) patients with psychiatric disorders, 11) patients with morbid obesity, 12) patients who can not cooperate, and 13) patients whose preoperative and postoperative serum sodium, potassium, calcium, magnesium, urea, creatinine, blood sugar, hemoglobin, and hematocrit values are detected to be abnormal. 
30 patients who were eligible for the study were given detailed information about the study and an informed consent form was signed. Forms detailing the patients' demographic characteristics and preoperative measurements were completed.

\section{Randomization:}

Patients included in the study were divided into 2 groups using a random number table. In Group I (n $=15)$ Levobupivacaine and in Group II $(n=15)$ Bupivacaine was performed (Figure 1).

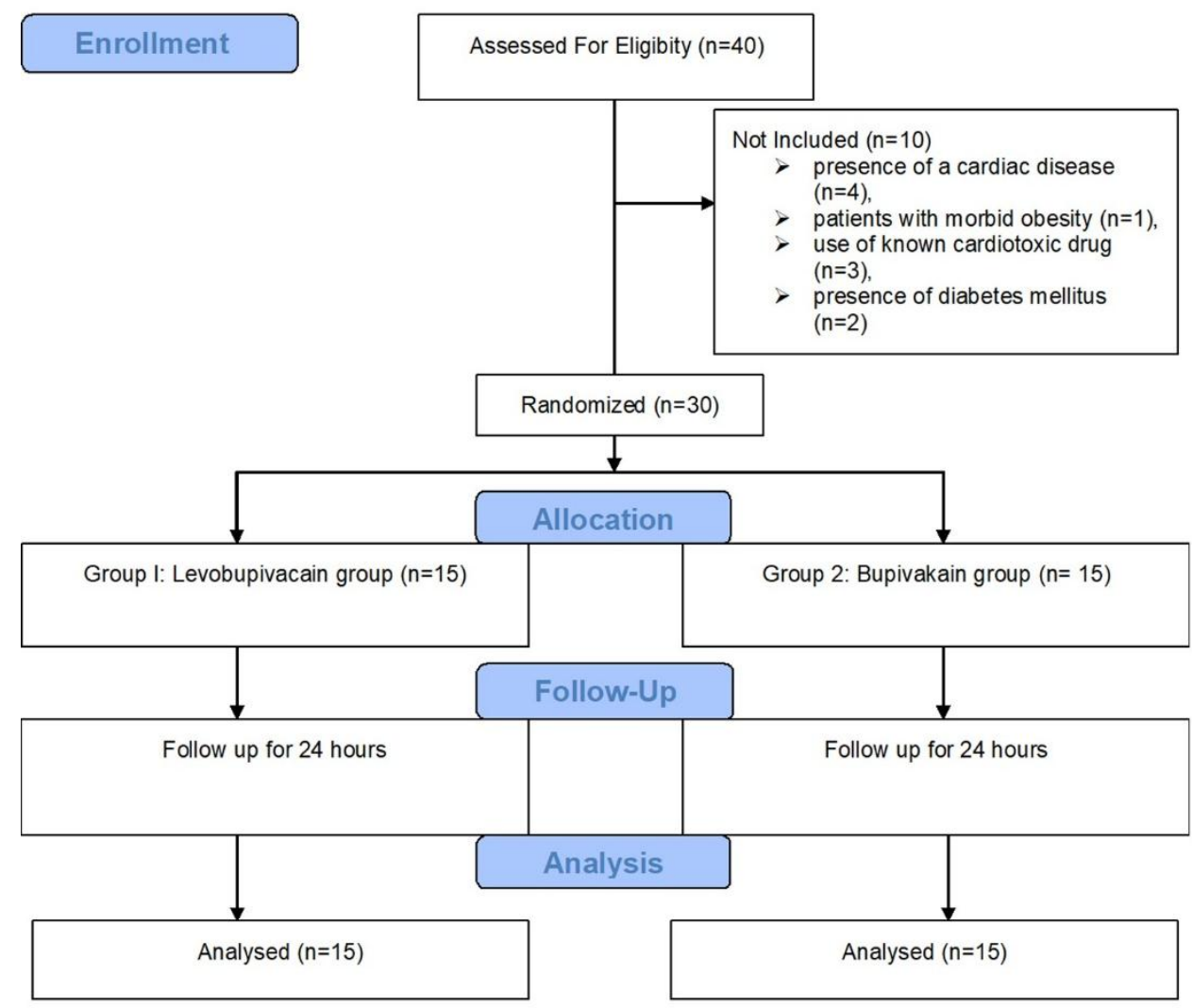

Figure 1: Flow chart of the study

\section{Interventions:}

Before surgery: Patients were taken to the block room 30 minutes before the procedure and IV infusion of $7 \mathrm{~mL} / \mathrm{kg} 0.9 \% \mathrm{NaCl}$ was started. Both groups were monitored as standard. These were noninvasive blood pressure [systolic arterial pressure (SAP), diastolic arterial pressure (DAP), mean arterial pressure (MAP)] and heart rate (HR).

Surgery Period: After the preoperative follow-up values of the patients were taken, they were sedated with IV Dormicum (loading dose: $0.015 \mathrm{mg} / \mathrm{kg}$ and id: $0.06 \mathrm{mg} / \mathrm{kg} / \mathrm{hr}$ ) in a separate vein route. Later, the patient was placed in a side-lying position and through the range $\mathrm{L}_{3-4}$ or $\mathrm{L}_{4-5}$ the epidural range was reached with 18 G Tuohy epidural needle by using the resistance loss method with saline, with openness towards cephal.The subarachnoid space was entered with a $27 \mathrm{G}$ spinal needle sent through the epidural needle. After the flow of cerebrospinal fluid (CSF) was observed, spinal anesthesia was completed by administering $15 \mathrm{mg}$ (3 cc) isobaric levobupivacaine in Group I and $15 \mathrm{mgr}(3 \mathrm{cc})$ isobaric bupivacaine in Group II. The spinal needle was retracted, the $20 \mathrm{G}$ epidural catheter was advanced through the epidural needle for $3 \mathrm{~cm}$, and the patient was brought to the supine position after being properly fixed. After appropriate site cleaning from the patients venous blood was collected 5 minutes after the spinal anesthesia procedure to determine the level BNP protein through the antecubital vein. The sensory 
block level was checked with a pinprick test every 5 minutes. When the sensory block reached $\mathrm{T}_{10}$, venous blood was collected from antecubital vein to measure again the level of BNP after appropriate field cleanup, and surgical procedure was started. During the operation, the patient was treated with a mask of $3 \mathrm{lt} / \mathrm{min} \mathrm{O}_{2}$ mask.

The first follow-up was accepted as 0 . minute immediately after the combined spinal epidural. SAP, DAP, and HR values were recorded and mean values were calculated from the 0 moment to the end of the surgery at the 5th, 10th, 15th, 20th, 25th, 30th, 45th, 60th, 90th, 120th minutes. During the surgery when HR was lowered to below 50 / min., atropine $0.5 \mathrm{mg}$ (IV) was applied and when OAP control value was lowered to below $20 \%$ ephedrine $10 \mathrm{mg}$ (IV) was applied.

Post Surgery Period: Patient was informed about patient-controlled analgesia (PCA) and the use of PCA device during the preoperative visit. With the termination of the surgery, the PCA device was connected to the epidural catheter and local anesthetic infusion was performed with PCA. The loading dose was not applied in PCA. The basal infusion rate was set at $4 \mathrm{~mL} / \mathrm{h}$, the bolus dose was $2 \mathrm{~mL}$, and the locking time was set to 30 minutes in PCA device. Concentrations in groups were: Group I: $1.25 \mathrm{mg} / \mathrm{ml}$ levobupivacaine, Group II: $1.25 \mathrm{mg} / \mathrm{ml}$ bupivacaine. SAP, DAP, $\mathrm{HR}$, visual analog scale (VAS) values were observed at postoperative follow-up time of 0 . min and at 1, 6, 12, 24 hours. In addition, diclofenac 75 $\mathrm{mg}$ (IM) was administered at times of VAS $>4$ and the data were recorded.

In addition, during the operation and post-operative period side effects occurred in the patients were followed and necessary treatments were performed. Nausea-vomiting, bradycardia, and hypotension were followed and recorded if observed. When these side effects were observed, metoclopramide was treated with $10 \mathrm{mg}$ (IV), atropine $0.5 \mathrm{mg}$ (IV), ephedrine $10 \mathrm{mg}$ (IV), respectively.
Venous blood samples were taken from antecubital vein at 24th postoperative hour for the measurement of BNP protein level after appropriate site cleanup.

\section{Evaluation Parameters:}

Blood samples were taken in a red capped dry biochemical tube and delivered to the biochemistry laboratory within 15 minutes after being taken. Serum BNP measurements were performed in our hospital's biochemistry laboratory. After centrifugation for $10 \mathrm{~min}$ at $5000 \mathrm{rpm}$, it was worked on Axsym device using the Abbott Axsym System BNP kit with the MEIA (microparticle enzyme immunoassay). Before testing, samples were brought to room temperature to ensure homogeneity. The results were given in $\mathrm{pg} / \mathrm{ml}$. Patients were assessed for BNP levels below or above $100 \mathrm{pg} / \mathrm{mL}$.

\section{Statistical Analysis}

SPSS 22.0 statistical package program was used to analyze the data. When the data were evaluated, frequency distributions, averages, standard deviations, percent values and cross tables were used. Categorical comparisons were made using Chi-Square or Fisher's exact test. In the study, Student's t-Test was used to compare the difference between the groups. The probability $(\mathrm{P})$ values $\alpha=$ 0.05 are considered to be significant and there is a difference between the groups, the larger values are considered to be insignificant and there is no difference between the groups.

\section{RESULTS}

The current study was completed with a total of 30 patients (Group I $n=15$, Group II $n=15$ ) (Figure 1). Distribution of age, gender, body mass index (BMI) of the patients are presented in Table 1 . There was no statistically significant difference between the two groups for demographic characteristics $(\mathrm{p}>0.05)$. 
Table 1: Comparison of the demographic characteristics of the patients (Mean $\pm \mathrm{SD}$ )

\begin{tabular}{|c|l|l|l|}
\hline & Group I $(\mathrm{n}=15)$ & Group II $(\mathrm{n}=15)$ & P \\
\hline Age (Year) & $62.67 \pm 4.66$ & $61.47 \pm 6.26$ & 0.845 \\
\hline Gender (M/F) & $1 / 14$ & $1 / 14$ & N/A \\
\hline BMI $\left(\mathrm{kg} / \mathrm{m}^{2}\right)$ & $30.42 \pm 3.44$ & $29.95 \pm 3.31$ & 0.705 \\
\hline Duration of Surgery (min) & $86 \pm 21.5$ & $90 \pm 18$ & 0.711 \\
\hline
\end{tabular}

M: Male, F: Female, BMI: Body mass index

There was no statistically significant difference in systolic arterial pressures ( $p>0.05)$ between the groups at all measurement times except for postoperative 1st hour. But there was a statistically significant difference $(\mathrm{p}<0.05)$ in the bupivacaine group at postoperative 1st hour (Table 2). Diastolic arterial pressures were not statistically different between groups at all measurement times ( $p>0.05)$ (Table 2).

Table 2: Comparison of the SAP and DAP values between the groups

\begin{tabular}{|l|l|l|l|}
\hline SAP & Group I $(\mathrm{n}=15)$ & $\begin{array}{l}\text { Group II } \\
(\mathrm{n}=15)\end{array}$ & $\mathrm{p}$ \\
\hline preoperative & $161.33 \pm 26.07$ & $148.07 \pm 19.76$ & 0.127 \\
\hline mean pressure during operation & $131.96 \pm 20.46$ & $124.22 \pm 17.97$ & 0.281 \\
\hline postoperative & $131.67 \pm 22.07$ & $121.80 \pm 12.19$ & 0.141 \\
\hline postoperative $1^{\text {st }}$ hour & $130.53 \pm 12.44$ & $120.67 \pm 10.63$ & $\mathbf{0 . 0 2 7}$ \\
\hline postoperative $6^{\text {th }}$ hour & $126.67 \pm 13.10$ & $124.40 \pm 11.58$ & 0.620 \\
\hline postoperative $2^{\text {th }}$ hour & $127.93 \pm 9.84$ & $124.07 \pm 8.84$ & 0.267 \\
\hline postoperative24 $4^{\text {th }}$ hour & $126.00 \pm 14.24$ & $118.80 \pm 8.51$ & 0.104 \\
\hline DAP & & & \\
\hline preoperative & $87.87 \pm 16.35$ & $84.67 \pm 11.65$ & 0.542 \\
\hline mean pressure during operation & $72.08 \pm 11.45$ & $71.10 \pm 11.17$ & 0.815 \\
\hline postoperative & $73.67 \pm 12.16$ & $67.67 \pm 7.83$ & 0.119 \\
\hline postoperative $1^{\text {st }}$ hour & $71.80 \pm 12.53$ & $69.60 \pm 5.42$ & 0.538 \\
\hline postoperative $6^{\text {th }}$ hour & $72.27 \pm 10.07$ & $74.40 \pm 6.62$ & 0.499 \\
\hline postoperative $12^{\text {th }}$ hour & $72.80 \pm 11.68$ & $72.53 \pm 8.90$ & 0.944 \\
\hline postoperative $24^{\text {th }}$ hour & $74.40 \pm 8.55$ & $69.15 \pm 6.62$ & 0.085 \\
\hline
\end{tabular}

SAP: systolic arterial pressure, DAP: diastolic arterial pressure 
Comparison of mean arterial pressures between groups; There was a statistically significant difference $(\mathrm{p}<0.05)$ at the end of the operation, postoperative 1 st hour and postoperative 24 th hour, in the bupivacaine group (Table 3). Comparison of heart rate between groups; There was no statistically significant difference between the groups at all measurement times except 24 hours postoperatively ( $p>0.05$ ). There was a statistically significant difference in the levobupivacaine group at postoperative 24th hour $(\mathrm{p}<0.05)$ (Table 3).

Table 3: Comparison of the MAP and heart rate values between the groups

\begin{tabular}{|l|l|l|l|}
\hline MAP & Group I (n=15) & $\begin{array}{l}\text { Group II } \\
(\mathrm{n}=15)\end{array}$ & $\mathrm{p}$ \\
\hline preoperative & $111.40 \pm 26.11$ & $104.60 \pm 11.93$ & 0.367 \\
\hline mean pressure during operation & $93.37 \pm 15.52$ & $88.31 \pm 13.93$ & 0.355 \\
\hline postoperative & $100.27 \pm 14.04$ & $88.67 \pm 11.02$ & $\mathbf{0 . 0 1 8}$ \\
\hline postoperative $1^{\text {st }}$ hour & $101.20 \pm 11.45$ & $90.27 \pm 7.87$ & $\mathbf{0 . 0 0 5}$ \\
\hline postoperative $6^{\text {th }}$ hour & $95.33 \pm 12.87$ & $92.87 \pm 10.03$ & 0.563 \\
\hline postoperative $12^{\text {th }}$ hour & $94.13 \pm 12.74$ & $95.60 \pm 8.92$ & 0.718 \\
\hline postoperative $24^{\text {th }}$ hour & $97.87 \pm 10.87$ & $90.33 \pm 8.72$ & $\mathbf{0 . 0 4 5}$ \\
\hline HEART RATE & & & 0.542 \\
\hline preoperative & $89.93 \pm 19.07$ & $93.53 \pm 12.11$ & 0.599 \\
\hline mean pressure during operation & $77.21 \pm 14.28$ & $79.50 \pm 8.60$ & 0.512 \\
\hline postoperative & $80.93 \pm 12.78$ & $78.00 \pm 11.38$ & 0.524 \\
\hline postoperative $1^{\text {st }}$ hour & $81.67 \pm 15.97$ & $78.40 \pm 11.41$ & 0.986 \\
\hline postoperative $6^{\text {th }}$ hour & $77.27 \pm 11.34$ & $77.33 \pm 9.21$ & 0.973 \\
\hline postoperative $12^{\text {th }}$ hour & $76.80 \pm 12.73$ & $76.93 \pm 8.08$ & 0.512 \\
\hline postoperative $24^{\text {th }}$ hour & $78.93 \pm 6.68$ & $81.20 \pm 6.46$ & \\
\hline
\end{tabular}

MAP: mean arterial pressure

Comparison of VAS values between groups; There was no statistically significant difference at all measurement times except postoperative 12 th and 24th hours ( $>>0.05)$. A statistically significant difference was found in the VAS values measured at postoperative 12th hour and 24th hour in favor of levobupivacaine group (p $<0.05$ ) (Table 4).

Table 4: Comparison of the VAS values between the groups

\begin{tabular}{|l|l|l|l|}
\hline VAS & Group I $(\mathrm{n}=15)$ & $\begin{array}{l}\text { Group II } \\
(\mathrm{n}=15)\end{array}$ & $\mathrm{p}$ \\
\hline postoperative & $2.47 \pm 1.46$ & $2.00 \pm 1.51$ & 0.397 \\
\hline postoperative $15^{\text {th }}$ minute & $3.00 \pm 1.89$ & $2.53 \pm 1.85$ & 0.500 \\
\hline postoperative $30^{\text {th }}$ minute & $3.07 \pm 1.49$ & $3.20 \pm 1.57$ & 0.813 \\
\hline postoperative $1^{\text {st }}$ hour & $3.53 \pm 1.19$ & $4.00 \pm 1.56$ & 0.364 \\
\hline postoperative $6^{\text {th }}$ hour & $3.60 \pm 1.24$ & $4.13 \pm 0.99$ & 0.204 \\
\hline postoperative $12^{\text {th }}$ hour & $3.47 \pm 1.06$ & $4.93 \pm 0.96$ & $<\mathbf{0 . 0 0 1}$ \\
\hline postoperative $24^{\text {th }}$ hour & $4.00 \pm 0.93$ & $4.93 \pm 1.10$ & $\mathbf{0 . 0 1 8}$ \\
\hline
\end{tabular}


In comparison between the BNP levels between the groups; no statistically significant difference was found between the two groups at all measurement times $(\mathrm{p}>0.05)($ Table 5).

Table 5: Comparison of the BNP values between the groups.

\begin{tabular}{|c|l|l|l|}
\hline BNP & Group 1 (n=15) & Group 2(n=15) & $\mathrm{p}$ \\
\hline $\begin{array}{c}\text { after injection } 15^{\text {th }} \text { minute } \\
\text { BNP }<100 \\
\text { BNP }>100\end{array}$ & $\begin{array}{l}12(\% 80) \\
3(\% 20)\end{array}$ & $\begin{array}{l}14(\% 93.3) \\
1(\% 6.7)\end{array}$ & 0.299 \\
\hline $\begin{array}{c}\text { when the sensory block reaches T10 } \\
\text { level }\end{array}$ & & & \\
BNP<100 & $13(\% 86.7)$ & $15(\% 100)$ & 0.153 \\
BNP $>100$ & $2(\% 13.3)$ & - & \\
\hline $\begin{array}{c}\text { postoperative } 24^{\text {th }} \text { hour } \\
\text { BNP }<100\end{array}$ & $11(\% 73.3)$ & $13(\% 86.7)$ & 0.379 \\
\hline
\end{tabular}

BNP: Brain Natriuretic Peptide

\section{DISCUSSION}

In our study in which combined spinal epidural anesthesia (CSEA) was used for total knee arthroplasty and for postoperative analgesia, we used bupivacaine and levobupivacaine in equal doses. As a result of our study, there was no statistically significant difference between preoperative, postoperative and postoperative 24th hour values in the BNP levels used to determine the cardiotoxic effects of the drugs given.

It is indicated that the cardiovascular toxicity potentials of local anesthetic drugs are due not only to the nerve cell membranes but also to the ion channels in excitable tissues such as the heart ${ }^{9}$. The primary mechanism of bupivacaine-induced cardiotoxicity has been reported as cardiac sodium channels and voltage-dependent potassium channels being blocked with bupivacaine and the prolongation of the duration of action of bupivacaine's cardiac action potential ${ }^{10}$. The enantiomers of bupivacaine have pharmacologically different properties and have been developed to reduce the risk of fatal arrhythmias that can occur with bupivacaine. Levobupivacaine is the (-) enantiomer of bupivacaine. Levobupivacaine shows similar pharmacokinetic properties to racemic bupivacaine, and studies have shown that the duration of effect onset and duration of effect and hemodynamic changes after spinal anesthesia of levobupivacaine is the same as that of bupivacaine ${ }^{7,11}$. It has been reported that the inhibitory effect of bupivacaine on sodium and potassium channels is more potent than levobupivacaine. Levobupivacaine has therefore been reported to be a new alternative in patients with cardiovascular disease. However, it is stated that studies with Levobupivacaine are not enough and more studies should be done ${ }^{12,13}$.

In the literature on cardiotoxicity of local anesthetics, animal studies and limited number of human studies have been tried to be shown ${ }^{13-19}$. In the first of these studies, Groban et al. injected high doses of bupivacaine, levobupivacaine, ropivacaine and lidocaine intravenously into the dogs and investigated their cardiotoxic effects. Lidocaine intoxication resulted in myocardial depression responding to resuscitation, whereas bupivacaine, levobupivacaine and ropivacaine did not always respond to resuscitation successfully. Mortality rates were $50 \%$ in bupivacaine, $30 \%$ in levobupivacaine, $10 \%$ in ropivacaine and $0 \%$ in lidocaine ${ }^{13}$.Other studies have reported that plasma concentrations of bupivacaine, levobupivacaine, and ropivacaine are similar when cardiovascular collapse occurs ${ }^{14}$. Ohmura et al. reported that there was no difference in plasma concentrations of bupivacaine, levobupivacaine, and ropivacaine when asystole occurred in anesthetized rats ${ }^{15}$. The 
ratio of bupivacaine, levobupivacaine and ropivacaine, which prolong the QRS period in isolated rabbit hearts, was found to be 1: 0.4: 0.3 in another study ${ }^{16}$.

In studies where people were used, local anesthetics were administered intravenously in small doses to volunteers and the toxicity of the local anesthetics on the cardiovascular system was investigated. As a result of the study, we found that ropivacaine and levobupivacaine are at the same level of toxicity but bupivacaine is more toxic than these ${ }^{17}$. In another volunteer study, there was a statistically significant difference only in the change in bupivacaine group despite the increase in PR interval and corrected QT (QTc) intervals in ECG of levobupivacaine and bupivacaine ${ }^{18}$. Salomaki et al. reported that levobupivacaine is a potent drug and that serious precautions should be taken to prevent intravenous administration in case reports in which they reported that they had observed cardiovascular collapse after unintentional intravenous infusion of levobupivacaine under general anesthesia and they treated without sequel ${ }^{19}$. In another study, epidural bupivacaine and levobupivacaine in cesarean section did not differentiate in QT interval measurements of $\mathrm{ECG}^{6}$.

Cardiovascular effects of local anesthetics can be observed with ECG findings but also biochemical markers can be used to detect cardiac dysfunction. In function disorders, many natriuretic peptides are released from the heart, and one of the most sensitive and up-to-date of these released peptides is the brain natriuretic peptide (BNP) ${ }^{8}$. It is stated in the literature that $\mathrm{BNP}$, apart from cardiac diseases, can also be used for cardiotoxicity, cardiac and noncardiac post-surgery situation, and cardiac status ${ }^{21,22,23}$.

For this purpose, NT-ProBNP levels before and after surgery were investigated in patients who underwent vascular surgery. They have reported that simple postoperative NT-ProBNP levels may lead to detecting structural myocardial injury ${ }^{21}$. In their studies Terasako et al. have suggested that elevated ANP and BNP levels in patients with hip arthroplasty may be indicative of insufficient myocardial reserves associated with hypotension and may allow detection of patients at risk for complications ${ }^{22}$. They also reported that, in a prospective cohort study of BNP levels to determine the risk of complications and increased mortality following major emergency non-cardiac surgery, BNP measurement is important for differentiating the patients with increased risk of preoperative cardiac events ${ }^{24}$. In their study
Vetrugno et al. have shown that BNP before and after surgery is predictive of significant cardiac side effects ${ }^{25}$.

Many of the studies in the literature on cardiotoxicity have been based on the effects of bupivacaine and levobupivacaine on cardiac message ${ }^{6,18}$. Although studies report that bupivacaine is more cardiotoxic, there are studies that have found cardiotoxic effects similar to levobupivacaine 14,15. When the studies are examined, there is no other study evaluating the cardiotoxic effects of different types of local anesthetic drugs with BNP.

The cardiotoxic effects of levobupivacaine and bupivacaine, which we determined as the aim of our study, were not different when evaluated with BNP. Unlike the literature, in this study the BNP pathologic limit value was determined and values over this limit value were accepted as significant or meaningful. In this study where $100 \mathrm{pg} / \mathrm{mL}$ was accepted as pathologic value, we think it is more important that there should be no difference between measurement times between the two groups. On the other hand, the veins in the nonvalvular structure on the epidural side are directly connected to the pelvic veins (lower), and intracranial veins (above), and to the thoracic and abdominal veins via intervertebral foramens. With this epidural injection, the local anesthetic delivered can reach these veins and from there to the heart or brain ${ }^{1,6} .24$ th hour BNP values were no different either between groups in order to detect cardiac effects of bupivacaine and levobupivacaine in infusion doses for this purpose. In hemodynamic parameters determined in other results of the study, differences in some measurement times do not seem meaningful as they are independent of BNP protein measurement times and is small in number.

Limitation: The lack of a placebo intervention group and the small number of patients are the obvious limitations of this study.

\section{CONCLUSION}

In these study results, similar results were obtained in intraoperative and postoperative BNP levels when using levobupivacaine and bupivacaine in equal doses for both spinal anesthesia and epidural analgesia.

\section{REFERENCES}

1. Erdine S, Özyalçın SN, Raj PP, et al. Rejyonal Anestezi. İstanbul: Nobel Tip Kitabevleri;2005; p.185-91.

2. Rawal N, Holmstrom B, Crowhurst JA, Van Zundert A. The combined spinal- epidural 
technique anesthesiology. Anesthesiol Clin North America. 2000; 18: 267-95.

3. Collins JV. Principles of Anaesthesiology. Third Edition. Philadelphia Lea and Febiger; 1993; p.1445-97.

4. Chester C, Bleckner LL. Anaesthetic agents for advanced regional anaesthesia. Drug. 2005; 65: 745-59.

5. Kayhan Z. Klinik Anestezi. 2. Bask1. İstanbul Logos Yayıncılık; 2004; p. 503-23.

6. Bader AM, Tsen LC, Camann WR, Nephew E, Datta S. Clinical effects and maternal and fetal plasma concentrations of \%0,5 epidural levobupivacaine versus bupivacaine for cesarean delivery. Anesthesiology. 1999; 90: 1596-601.

7. Casati A, Moizo E, Marchetti C, Vinciguerra F. A prospective, randomized, double-blind comparison of unilateral spinal anesthesia with hyperbaric bupivacaine, ropivacaine, or levobupivacaine for inguinal herniorrhaphy. Anesth Analg. 2004; 99:1387-92.

8. Suttner SW, Boldt J. Natriuretic peptide system: physiology and clinical utility. Curr Opin Crit Care. 2004;10: 336-41.

9. Valenzuela C, Snyders DJ, Bennett PB, Tamargo J, Hondeghem LM. Stereoselective block of cardiac sodium channels by bupivacaine in guinea pig ventricular myocytes. Circulation.1995; 92: 3014-24.

10. Kawano T, Oshita S, Takahashi A, et al. Molecular mechanisms of the inhibitory effects of bupivacaine, levobupivacaine, and ropivacaine on sarcolemmal adenosine triphosphate-sensitive potassium channels in the cardiovascular system. Anesthesiology. 2004; 101: 390-8.

11. Cuvas O, Er AE, Ongen E, Basar H. Spinal anesthesia for transurethral resection operations: bupivacaine versus levobupivacaine. Minerva Anestesiol. 2008;74:697-701.

12. Fatorini F, Ricci Z, Rocco A, et al. Levobupivacaine versus racemic bupivacaine for spinal anaesthesia in orthopaedic major surgery. Minerva Anesttesiol. 2006; 72: 637-44.

13. Groban L, Deal DD, Vernon JC, James R L, Butterworth J. Cardiac resuscitation after incremental overdosage with lidocaine, bupivacaine, levobupivacaine, and ropivacaine in anesthetized dogs. Anesth Analg. 2001; 92: 37-43.

14. Groban L, Deal DD, Vernon JC, James RL, Butterworth J. Ventricular arrhythmias with or without programmed electrical stimulation after incremental overdosage with lidocaine, bupivacaine, levobupivacaine, and ropivacaine. Anesth Analg. 2000; 91: 1103-11.

15. Ohmura S, Kawada M, Ohta T, Kobayashi T. Systemic toxicity and resuscitation in bupivacaine, levobupivacaine or ropivacaine infused rats. Anesth Analg 2001; 93: 743-8.

16. Mazoit JX, Decaux A, Bouaziz H, Eduard A. Comparative ventricular electrophysiologic effect of rasemic bupivacaine, levobupivacaine and ropivacaine on the isolated rabbit heart. Anesthesiology 2000; 93: 784-92.

17. Stewart J, Kellett N, Castro D. The central nervous system and cardiovascular effects of levobupivacaine and ropivacaine in healthy volunteers. Anesth Analg. 2003;97: 4126.

18. Bardsley H, Griswood R, Baker H, Nimmo W. A comparison of the cardiovasculer effects of levobupivacaine and rac-bupivakaine following intravenous administration to healty volunteers. $\mathrm{Br}$ J Clin Pharmacol 1998; 46: 245-9.

19. Salomaki TE, Laurilla PA, Ville J. Succesfull resuscitation after cardiovaskular collaps following accidental intravenous infusion of levobupivacaine during general anesthesia. Anesthesiology 2005; 103: 1095-6.

20. Karakılıç E, M Ali Karaca, Bozkurt Ş, Coşkun F, Sivri B. BNP Nedir? Acil Serviste Beyin Natriüretik Faktör (BNP) Kullanımı. Akademik Acil Tip dergisi. 2005; 3: 7-10.

21. Mahla E, Baumann A, Rehak P, et al. N-terminal pro-brain natriuretic peptide identifies patients at high risk for adverse cardiac outcome after vascular surgery. Anesthesiology. 2007; 106:108895.

22. Terasako K. Perioperative plasma concentrations of atrial and brain natriuretic peptides in patients undergoing hip arthroplasty. Anaesth Intensive Care. 2002; 30: 588-90.

23. Pongprot Y, Sittiwangkul R, Charoenkwan P, Silvilairat S. Use of Cardiac Markers for Monitoring of Doxorubixin-induced Cardiotoxicity in Children With Cancer. Journal of Pediatric Hematology/Oncology. 2012; 34: 58995.

24. Cuthbertson BH, Card G, Croal BL, McNeilly J, Hillis GS. The utility of B-type natriuretic peptide in predicting postoperative cardiac events and mortality in patients undergoing major emergency non-cardiac surgery. Anaesthesia. 2007; 62: 87581. 
25. Vetrugno L, Langian N, Gisonni R, et al. Prediction of early postoperative major cardiac events after elective orthopedic surgery: the role of B-type natriuretic peptide, the revised cardiac risk index, and ASA class. BMC Anesthesiology. 2014; 14: 20. 